\title{
Discussing Stalinism. Problems and Approaches
}

\author{
Markku Kangaspuro \& Vesa Oittinen (red.) \\ Aleksanteri Institute: University of Helsinki 2015 \\ 122 sidor. ISSN 08017220
}

Recenserad av Ingmar Oldberg [associerad forskare, Utrikespolitiska institutet, Stockholm, Sverige, ingmar.oldberg@gmail.com]

Denna antologi bygger på ett symposium vid Aleksanteri-institutet, som hölls redan 2011 och ett par av artiklarna har också publicerats därefter på annat håll. Inledningsvis presenterar redaktörerna de två i väst dominerande skolorna i synen på stalinismen, nämligen den totalitaristiska och den revisionistiska, med hjälp av George Breslauer. Den förstnämnda skolan fokuserar på sovjetsystemets ideologi och den monolitiska partiledningens politik \top-down», typ Richard Pipes och Martin Malia, medan »revisionisterna» företrädda av till exempel Stephen Cohen och Sheila Fitzpatrick studerar sovjetsamhällets interaktion mellan politik, ekonomi och samhälle »bottom-up». Till dessa fogar redaktörerna en tredje skola efter Sovjets fall, som tar fasta på politisk kultur, med Stephen Kotkin och David L. Hoffman som exempel. Kotkin såg Stalins terrorregim som ett kollektivt företag för att skapa ett nytt samhälle, Hoffman som en version av modernisering rotad i den europeiska upplysningstiden.

Redaktörerna tar ställning för de senare skolorna. De dömer ut totalitarismbegreppet, som inte anses påvisa väsentliga skillnader mellan fascism/nazism och stalinism, och tar därmed avstånd från dem som såg många likheter. De finner ingenting i den ursprungliga marxismen som skulle sanktionera Stalins terror, och poängterar att stalinismen inte bara var våld och terror. De gillar Jörg Baberowskis tolkning av stalinismen, enligt vilken våld måste ses som en process och en smitta, och ser en viss logik i Arch J. Gettys och Oleg V. Naumovs slutsats att terrorn var oplanerad, eftersom det inte fanns verklig planering någonstans. Antologin syftar följaktligen till att belysa stalinismen som ett socio-kulturellt fenomen och sådana experter som Andrej Zubov och Anne Appelbaum nämns inte ens.

Det längsta kapitlet av ekonomhistorikern Lennart Samuelson är en fyllig historiografi över Stalinforskningen sedan 1930-talet, som haft särskild betydelse i Sverige och internationellt. Men bara en svensk, Anton Karlgren, refereras. Samuelson presenterar pionjärer som Boris Souvarine, Isaac Deutscher och Charles Bettelheim (utan att nämna att den förste var trotskist och den tredje blev maoist). Robert Conquest kritiseras hårt för att överdriva antalet dödsoffer i Gulag och påstås hävda att 
främst partikadrer drabbats och återspegla kalla-krigsuppfattningar. Men Samuelson medger att Conquest saknade primärkällor och att denne ändrade sig då sådana kom. Han gillar Cohens kritik av totalitarismskolan, som hävdas bortse från sociala krafter och se samhället som helt kontrollerat uppifrån. Enligt honom (i motsats till redaktörerna) ansåg visserligen Getty \& Naumov att utrensningarna helt kontrollerades av Stalin, men han ställer frågan om terrorn var stalinismens väsen.

Samuelson fäster stor vikt vid glasnost och 1990-talets »arkivrevolution», som ledde till publicering av en mängd källmaterial, ny forskning, memoarer, intervjuprojekt och översättning av västforskning. Han noterar att de ryska forskarna i början övertog mycket av totalitarismskolans vokabulär och gjorde nya upptäckter av hur Stalins maktapparat, terrorn och Gulagsystemet utvecklades och fungerade i detalj. Bland annat presenteras Nikita Petrov och Arsenij Roginskij i Memorial, Vladimir Chaustov, Niels Erik Rosenfeldt, Oleg Chlevnjuk och Andrej Sorokin. Samuelson stämplar dock den franska Kommunismens svarta bok som ett »ideologiskt» projekt och perestrojka-ideologen Aleksandr Jakovlevs bidrag till den som »politiserat». Som motvikt framhävs Moshe Lewin och hans The Soviet Century, som kombinerar social, ekonomisk och politisk analys.

Mot slutet observerar Samuelson en växande ström av prostalinistiska böcker i Ryssland under senare år och uppmanar den akademiska forskningen att med säkra fakta bekämpa denna (liksom populära Stalin-biografier som Simon Montefioris). Han förtiger dock att den politiska ledningen under Putin numera i praktiken uppmuntrar en rehabilitering av Stalin, samtidigt som tillgången till arkiven åter försvårats. Sedermera har Samuelson fått Rysslands vänskapsorden ur Putins hand.

Petersburg-professorn Michail Maslovskij granskar i sitt bidrag Stalins regim med hjälp av Max Webers sociologi och legitimeringstyper. Han ser en övergång från Lenins »rationella» till Stalins genom personkult konstruerade karisma och betecknar regimen som en "patrimonial» byråkrati, där makten vilar på personliga relationer mellan ledare och undersåtar. Han presenterar sedan två neo-weberianer: Michael Mann hör till dem som ser Stalins och Hitlers regimer som totalitära men anser att de tillskriver regimerna alltför mycket kontroll. Johann Arnason anlägger i stället ett kulturellt perspektiv med tal om olika moderniseringsstrategier och pekar på att regimen åter legitimerades genom segern i andra världskriget och den följande expansionen. Maslovskij anser att synsätten borde kunna kombineras med hänsyn till både sociala och kulturella faktorer.

Vesa Oittinen gör sedan en intressant analys av hegelianska tolkningar av Stalintiden hos Bertolt Brecht, Georg Lukács och Nikolaj Bucharin. Inför alternativet Hitler och i kunskap (?) om offren stödde Brecht under 1930-talet ändå Stalin, som ansågs ha nått goda resultat. Lukács såg Stalin som en världshistorisk personlighet och ett redskap för det goda, varvid han jämförde med Napoleon, men han blev mer kritisk efter kriget. Den franske hegelianen Alexandre Kojève (Kozjevnikov) gick längre än Lukács och ansåg att terrorn var ett nödvändigt medel på vägen till det goda samhället. Bucharin hyllade under Moskva-processen 1938 Stalin som världens hopp och språkrör men gjorde hegelianska reservationer. 
Kollegan Markku Kangaspuros bidrag handlar om stalinismen som ett strategiskt val för att lösa ett av landets svåraste problem, nämligen förhållandet mellan centrum och periferi. Detta gör han genom en fin analys av hur centralmakten steg för steg tog total kontroll över Sovjet-Karelen. Avslutningsvis hävdar han att Sovjetunionen i början hade förutsättningar att utvecklas i en mindre auktoritär riktning, men är ändå osäker på om dessa hade kunnat garantera en mer hållbar och human utveckling.

Skotten Iain Lauchlans bidrag är en psykohistorisk analys av Tjekans grundare Feliks Dzerzjinskij. Han finner en rad tankeväckande likheter med Stalins utveckling, vilket skapade otålighet, våldsbenägenhet och paranoia. Han konkluderar att stalinismen och dess metoder (bortsett från strukturella faktorer) mer var en produkt av gruppmentalitet än av en enda persons psyke. Avslutningsvis diskuterar brasilianaren C.E.R. de Mendoza Trotskijs syn på det sovjetiska samhällets klasskaraktär och ägarförhållanden. Han kommer fram till att stalinismen visserligen blev en alltmer immateriell ideologi men ändå ger »mening och riktning i aktuell praktik», vilket enligt honom visar marxismens relevans än idag.

Sammantaget ger antologin en bred överblick över stalinforskningen, men det finns en slagsida åt det marxistiska hållet som gör den lite nattstånden. Det kan även påpekas att vissa kapitel borde ha språkgranskats bättre. 